\title{
Antibacterial Study of Gellan Gum (GG) Film Incorporated Norfloxacin
}

\author{
Nur Arifah Ismail, Khairul Anuar Mat Amin (D) and Mohd. Hasmizam Razali* \\ School of Fundamental Science, Universiti Malaysia Terengganu, 21030 Kuala Terengganu, Terengganu Darul \\ Iman, Malaysia.
}

\begin{abstract}
A series of norfloxacin-loaded films were fabricated by combining with gellan gum (GG) using evaporative casting technique. The films were evaluated in terms of morphological, water vapour transmission rates (WVTR), water uptake, release study and antibacterial study. The prepared films contained smooth appearance of cross-section distributed by good film of materials. The results indicated that the film swelling were increased at higher concentration of norfloxacin loaded, however decreased the WVTR properties. All films showed almost $\mathbf{1 0 0} \%$ of drug release within $\mathbf{5}-\mathbf{2 0}$ minutes. It was found that, the antibacterial activity was directly proportional to the release rate which is at higher concentration of norfloxacin resulted in stronger antibacterial properties.
\end{abstract}

Keywords: Gellan gum; Film; Antibacterial.

\footnotetext{
*Correspondence: mdhasmizam@umt.edu.my

(Received: 30 January 2019; accepted: 07 March 2019)
}

Citation: Nur Arifah Ismail, Khairul Anuar Mat Amin, and Mohd. Hasmizam Razali, Antibacterial Study of Gellan Gum (GG) Film Incorporated Norfloxacin, J Pure Appl Microbiol., 2019; 13(2): 1095-1102. doi: 10.22207/JPAM.13.2.48

(c) The Author(s) 2019. Open Access. This article is distributed under the terms of the Creative Commons Attribution 4.0 International License which permits unrestricted use, sharing, distribution, and reproduction in any medium, provided you give appropriate credit to the original author(s) and the source, provide a link to the Creative Commons license, and indicate if changes were made. 


\section{INTRODUCTION}

Gellan gum (GG) is a microbial exopolysaccharides produced from Sphingo-monas group and holds a vital role in therapeutic and manufacturing. It has been broadly used as stabilizers, thickening and gelling agent, emulsifiers and etc. ${ }^{1}$ in food industry since it has been approved by US FDA (United States Food and Drug Administration) and EU (European Union) regulation labelled as E 415 for food applications ${ }^{2}$. GG are among of the biopolymers that are currently used for commercial product and have been subjected for extensive study ${ }^{3}$. It was attract attention among the researcher since 1980 regarding to their unique structure and rheology properties that can form pseudo-solid structures or transparent hydrogeleven at low concentrations of their usage ${ }^{4}$. Not limited to that, it is a multifunctional gelling agent ${ }^{5}$, and has high potential to be apply in industrial as a high-viscosity biogum, a suspending agent and acts as a gelling agent ${ }^{6}$. Previously, GG has been use in development of scaffold material in tissue engineering application ${ }^{7}$, as a vehicle for ophthalmic drugs ${ }^{8}$, and in eye drops $^{9}$. It is also reported to biocompatible on live cells eg. mouse fibroblast (L929 cell line $)^{10}$, human dermal fibroblasts (HDFs), human fetal osteoblasts (hFOBs 1.19) ${ }^{11}$, human nasal cartilage ${ }^{12}$, rat bone marrow cells (rBMC) [7] and has been used in treating defects for rabbit knee joints ${ }^{13}$. Besides that, $\mathrm{GG}$ also presented their potential for wound dressing application since it is favorable for cell proliferation ${ }^{14-16}$. The gellan gum ability also has been used in production of an easy-to-swallow solid dosage forms likes gels and coated tablets. This is due to the release rate of active ingredients inside the tablets and capsules can be modified by using the gellan gum. So, it is favorable to use in controlled and sustained the releasing of variety types of drugs ${ }^{1,17}$ as well as for microencapsulation preparation. In this study, norfloxacin were selected as an antibiotic model due to its strong antibacterial properties. Norfloxacin is a fluoroquinolone with a broadspectrum activity against gram-positive and gram-negative bacteria, including Staphylococcus aureus, Pseudomonas aeruginosa, Escherichia coli, Salmonella, Campylobacter, Vibrio cholera and Shigella ${ }^{18-20}$. Norfloxacin effectively execute grampositive and gram-negative bacteria, however it has limitation against anaerobes bacteria ${ }^{21}$. Since few years ago, norfloxacin was become subject of interest for drug delivery study especially in biological and pharmaceutical field ${ }^{22-25}$. Norfloxacin has been used in treated common and complicated urinary tract infections such as cystitis and prostitis ${ }^{26,27}$ as well as effectively in treated gonococcal urethritis and infectious diarrhea ${ }^{28}$. Currently, it was effectively used as antibacterial in wound dressing materials ${ }^{29,30}$. So, in this work, norfloxacin were incorporated into gellan gum to develop medicated film for wound dressing application. This medicated film was importance to enhance the healing process by controlling the moisture around the wound area as well as to protect the skin from infections and dehydration that could be led to the tissue damaging and producing scar.

\section{MATERIALS AND METHODS}

Low-acyl gellan gum (Gelzan ${ }^{\text {TM }} \mathrm{CM}, \mathrm{Mw} \mathrm{H}$ " 2-3 $\times 10^{5} \mathrm{Da}$, product number-G1910, lot number SLBB0374V) was purchased from Sigma-Aldrich, Malaysia. Norfloxacin (product number-N9890) used in this work was supplied from Fluka, USA. All materials were used as received without further purification and commercially available.

\section{Preparation of Film}

Gellan gum (GG) solution was prepared by dissolving $1 \%(w / v)$ of $G G$ in $100 \mathrm{~mL}$ deionized water (18.2 MS) with continuous stirring for $2 \mathrm{~h}$ at $70^{\circ} \mathrm{C}$. GG-NOR solutions were made by adding $0.01 \%, 0.1 \%, 0.5 \%$ and $1 \%(w / w)$ norfloxacin (NOR) into the GG solution. Then, the GG and GG-NOR solutions were deposited into petri dishes $(90 \mathrm{~mm}$ $x 15 \mathrm{~mm}$ ) and were put in Venticell oven at $30^{\circ} \mathrm{C} \mathrm{for}$ $24 \mathrm{~h}$. All films were pre-conditioned in a desiccator $\left(24^{\circ} \mathrm{C}, 50 \%\right.$ relative humidity $\left.(\mathrm{RH})\right)$ for at least 2 days prior to testing.

\section{Characterization of Film}

The Ultraviolet (UV-vis) absorption spectra of solutions and films were collected via spectrophotometer (Varian, Cary 50) with data interval $=5 \mathrm{~nm}$, scan rate $=24000 \mathrm{~nm} / \mathrm{min}$ at 200-800 nm of wavelength. Quartz cells of path length at $10 \mathrm{~mm}$ were applied. Scanning electron microscopy (SEM) images were obtained by using a JOEL JSM 6360 LA electron microscope. SEM images of cross-sections were obtained by freezedrying the samples in liquid nitrogen $\left(-160^{\circ} \mathrm{C}\right)$ and 
were fractured at $-150^{\circ} \mathrm{C}$. Prior to observe via SEM, the samples were coated with Auto Fine Coats (JFC-1600). Swelling performance was evaluated by weighing the dried films $\left(\mathrm{W}_{\text {dry }}\right)$ before soak into solutions at $\mathrm{pH} \mathrm{1,} \mathrm{pH} \mathrm{7,} \mathrm{and} \mathrm{pH} 12$ in water bath $\left(37 \pm 0.5^{\circ} \mathrm{C}\right)$. Then, after $24 \mathrm{~h}$, prior to weighed $\left(W_{\text {wet }}\right)$ the films were removed from the solutions and were wiped gently with a tissue to expel any solution on the film surfaces. Swelling percentage was calculated from the equilibrium-swelling ratio $\left(\mathrm{W}_{\text {wet }}-\mathrm{W}_{\mathrm{dry}}\right) / \mathrm{W}_{\mathrm{dry}}$. The water vapor transmission rates (WVTR) was determined based on ASTM International standard method by some of the modification. The films were fixed on the circular opening of a permeation bottle with diameter at $1.5 \mathrm{~cm}$, height at $5.0 \mathrm{~cm}$, and effective transfer area (A) at1.33 $\mathrm{cm}^{2}$ and placed in a desiccator $\left(25^{\circ} \mathrm{C}\right.$ and $50 \pm 5 \% \mathrm{RH}$ ) for controlled the environment moisture. The WVTR was then measured by determined the rate of change of mass $(\mathrm{m})$ in these water-filled permeation bottles at $24 \mathrm{~h}$ exposure time of $24 \mathrm{~h}$ using Equation 1:

$$
\text { WVTR }=(m / \mathrm{A} \Delta t)
$$

where $\mathrm{m} / \Delta t$ is water gain per unit time of transfer and $A$ is the area exposed to water transfer $\left(\mathrm{m}^{2}\right)$.

\section{Antibacterial Assay}

The antibacterial activity was tested using Gram-positive (Staphylococcus aureus - S. aureus) and gram-negative (Escherichia coli - E. coli) bacteria. The standard growth medium of MullerHinton, (MH) Difco ${ }^{\mathrm{TM}}$ agar was sterilized using autoclave at $120^{\circ} \mathrm{C}$ for $15 \mathrm{~min}$. The bacteria were grown in $\mathrm{MH}$ agar and incubated aerobically at $37^{\circ} \mathrm{C}$ for $24 \mathrm{~h}$. The suspensions were measured by using spectrophotometer (Biomerieux Densicheck

Table 1. The water vapour transmission rates (WVTR) and swelling properties of GG and GG-NOR films (mean $\pm S D)(n=3)$

\begin{tabular}{lccccc}
\hline Sample & \multicolumn{2}{c}{ WVTR } & & \multicolumn{2}{c}{ Swelling (\%) } \\
\cline { 2 - 3 } & $\left(\mathrm{g} \mathrm{m}^{-2} \mathrm{~d}^{-1}\right)$ & $\mathrm{pH} 1$ & & $\mathrm{pH} 7$ & $\mathrm{pH} 12$ \\
\hline GG & $422 \pm 113$ & $308 \pm 15$ & & $987 \pm 113$ & $724 \pm 11$ \\
GG-NOR001 & $320 \pm 35$ & $310 \pm 12$ & & $1199 \pm 55$ & $814 \pm 37$ \\
GG-NOR01 & $353 \pm 2$ & $307 \pm 20$ & & $1123 \pm 47$ & $791 \pm 24$ \\
GG-NOR05 & $344 \pm 63$ & $281 \pm 18$ & & $1219 \pm 81$ & $809 \pm 44$ \\
GG-NOR1 & $337 \pm 7$ & $263 \pm 16$ & & $1284 \pm 18$ & $859 \pm 30$
\end{tabular}

Plus, USA) at $600 \mathrm{~nm}$ with optical density at 0.5 . The antibacterial activity of GG and GG-NOR film samples were tested against Gram-positive (Staphylococcus aureus - S. aureus) and gramnegative (Escherichia coli - E. coli) bacteria. The assessment was conducted based on the disc diffusion method. Inoculants of both $S$. aureus and $E$. coli were spread using sterile cotton swab over the surface of the agars in sterile petri plates. Peniccilin was used as a control for the bacteria. Each of the specimens and controlled drugs were placed on the standard growth medium of Muller-Hinton, $\mathrm{MH}$, Difco ${ }^{\mathrm{TM}}$ agar in sterilized petri plates and then incubated for $24 \mathrm{~h}$ at $37^{\circ} \mathrm{C}$ in triplicates. Prior to gently press of the films in $6 \mathrm{~mm}$ of their diameter, the plates that contained both of the bacteria were let to dry. After $24 \mathrm{~h}$ of aerobically incubation, the plates were examined for the presences of clear zone around the disc of specimens were then photograph using Samsung 13-megapixel Samsung camera for further evaluation.

\section{RESULTS AND DISCUSSION}

UV-visible spectroscopy of gellan gum (GG) with norfloxacin films at different concentrations are shown in Fig. 1. An absorption peak for free-standing GG was observed at $260 \mathrm{~nm}$ due to the presence of glucoranic acid group ${ }^{31-32}$. The pure norfloxacin band at $272 \mathrm{~nm}$ was shifted in GG-NOR blends ( $\geq 0.1 \%$ of norfloxacin added) to $280 \mathrm{~nm}$, indicating an interaction between both polymers $^{33-35}$. The absorption intensity of the peak was increased depending on the concentration of norfloxacin included in the GG film. The UV-vis absorption peak of GG-NOR001 which contains the

Table 2. Inhibition zone of gellan gum and gellan gum incorporated with norfloxacin against Staphylococcus aureus and Escherichia coli (mean $\pm S D)(n=3)$

\begin{tabular}{lcc}
\hline \multirow{2}{*}{ Mest bacteria } & \multicolumn{2}{c}{ Inhibition zone $(\mathrm{mm})$} \\
\cline { 2 - 3 } Material & S.aureus & E.coli \\
\hline GG & - & - \\
Penicillin & - & - \\
GG-NOR001 & $5.3 \pm 0.06$ & $5.0 \pm 0.01$ \\
GG-NOR01 & $11.0 \pm 0.06$ & $11.3 \pm 0.06$ \\
GG-NOR05 & $12.7 \pm 0.12$ & $13.0 \pm 0.10$ \\
GG-NOR1 & $13.0 \pm 0.01$ & $14.3 \pm 0.06$
\end{tabular}


lowest content of norfloxacin at $275 \mathrm{~nm}$ shifted to longer wavelength for GG-NOR05 and GG-NOR1 to $280 \mathrm{~nm}$ with increased absorption indicating the increase in cross-linking network of the composite. From the scanning electron microscopy photographs as shown in Fig. 2, smooth crosssection of GG-NOR films were observed which shows that the norfloxacin was distributed well in
GG solution. In addition, the formation of smooth cross-section is caused by the good film forming property ${ }^{36-38}$ between gellan gum and norfloxacin.

In Table 1, the water vapour transmission rate (WVTR) values are shown for gellan gum (GG) and GG incorporated with norfloxacin (NOR). The WVTR values were decreased with addition of norfloxacin into the gellan gum film. The water

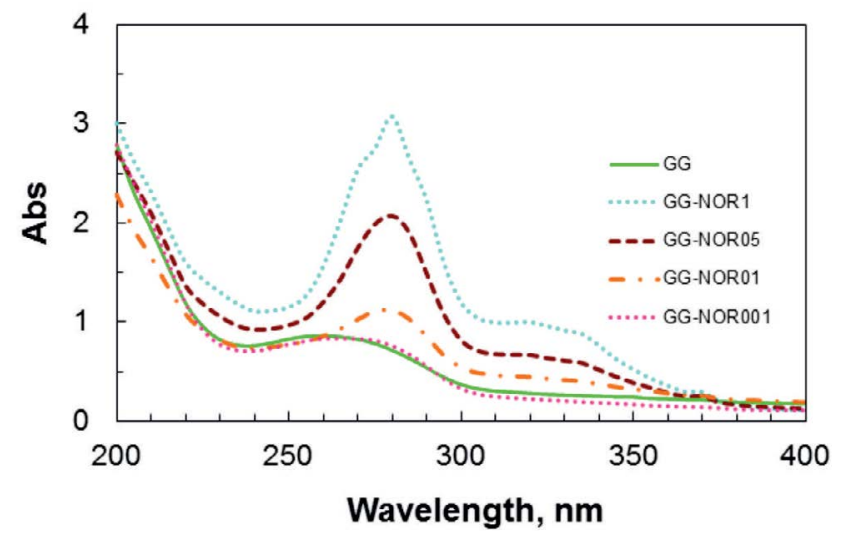

Fig. 1. UV-Visible absorbance of pure GG and GG-NOR films.
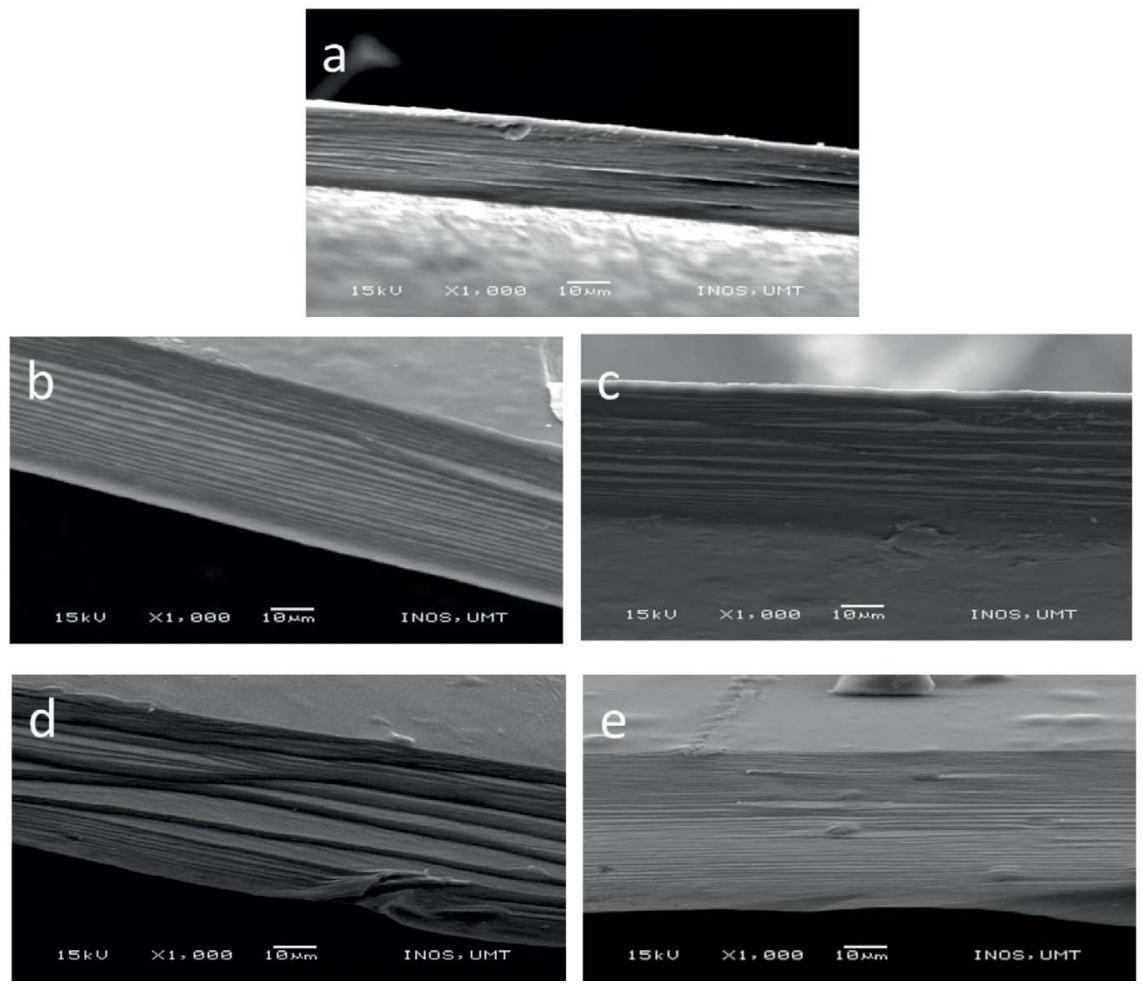

Fig. 2. Scanning electron microscopy images of cross-sectional area of (a) GG, (b) GG-NOR001, (c) GG-NOR01, (d) GG-NOR05, and (e) GG-NOR1 films. 
vapour transmission rates of GG-NOR001 have decreased about $24 \%$ compared to GG. Further, the water vapour transmission rates of GG-NOR01, GG-NOR05, and GG-NOR1 were decreased to
$353 \pm 2 \mathrm{~g} \mathrm{~m}^{-2} \mathrm{~d}^{-1}, 344 \pm 63 \mathrm{~g} \mathrm{~m}^{-2} \mathrm{~d}^{-1}$, and $337 \pm 7 \mathrm{~g} \mathrm{~m}^{-2}$ $\mathrm{d}^{-1}$, respectively compared to $G G$ films.

Table 1 presents the swelling properties of gellan gum and gellan gum inclusion with

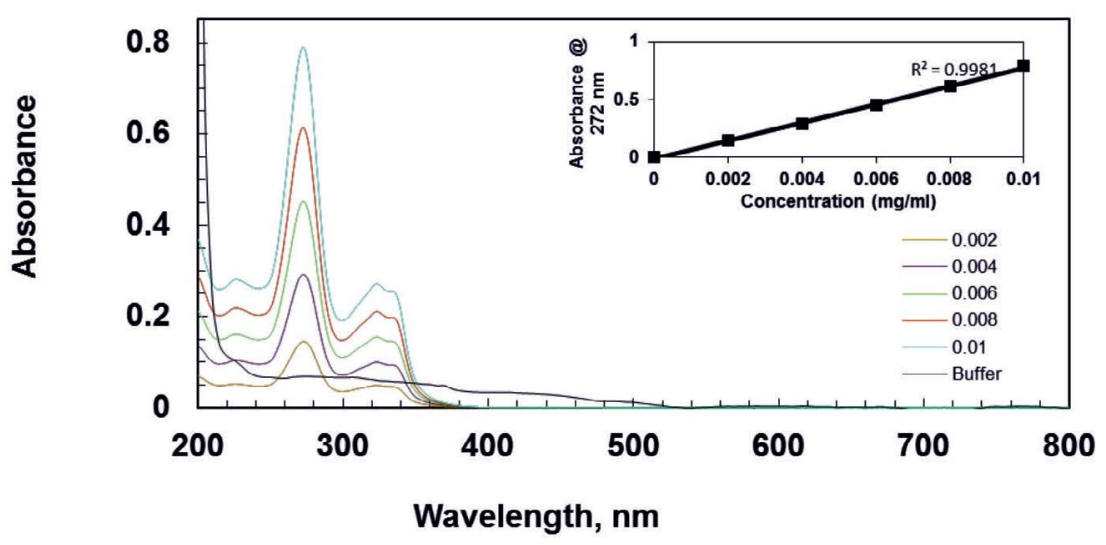

Fig. 3. Spectra of norfloxacin at different concentration.

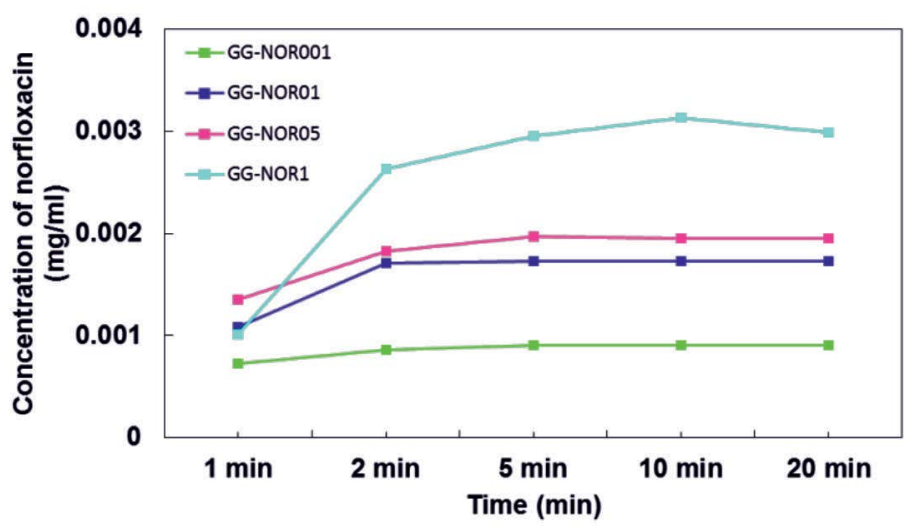

Fig. 4. Graph of releasing property through GG-NOR001, GG-NOR01, GG-NOR05, and GG-NOR1 films.
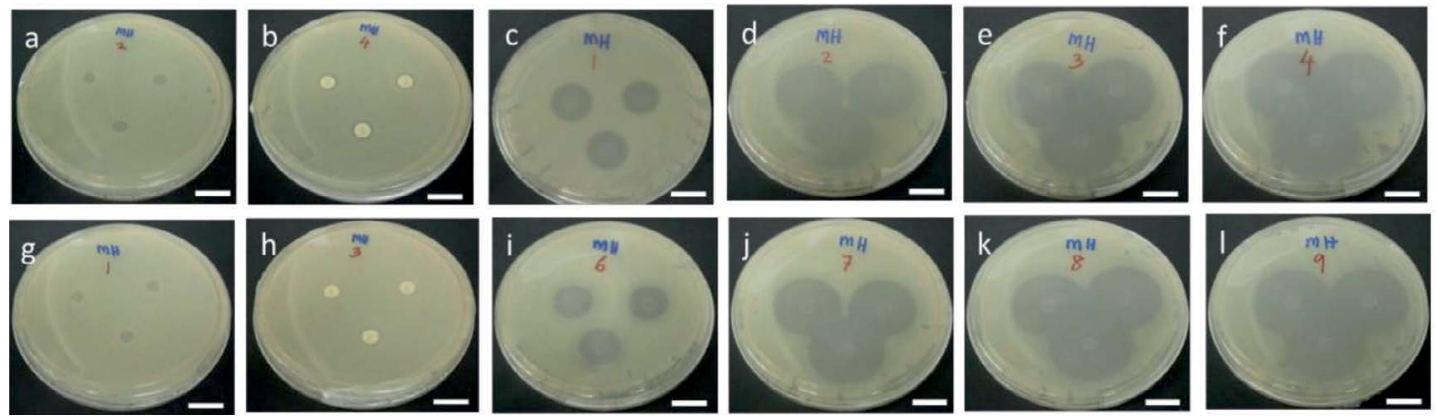

Fig. 5. Disk diffusion results of (a) GG (negative control), (b) penicillin (positive control), (c) GG-NOR001, (d) GGNOR01, (e) GG-NOR05, and (f) GG-NOR1 films against Escherichia coli, respectively, and (g) GG (negative control), (h) penicillin (positive control), (i) GG-NOR001, (j) GG-NOR01, (k) GG-NOR05, and (I) GG-NOR1 films against Staphylococcus aureus. Scale bar represents $2 \mathrm{~cm}$. 
norfloxacin film at different concentrations. The inclusions of norfloxacin into the gellan gum matrix led to the increased of water absorption in $\mathrm{pH} 7$ and $\mathrm{pH}$ 12. The inclusion of $0.01 \%(\mathrm{w} / \mathrm{w})$ norfloxacin to the gellan gum increased the swelling percentage in $\mathrm{pH} 1, \mathrm{pH} \mathrm{7}$, and $\mathrm{pH} 12$ to $310 \%, 1199 \%$, and $814 \%$ compared to gellan gum films at $308 \%, 987$ $\%$, and $724 \%$, respectively. However, increased the concentration of norfloxacin to gellan gum decreased the swelling properties except in $\mathrm{pH} 7$ and $\mathrm{pH}$ 12. This is due to the different $\mathrm{pH}$ environment of buffer solution. Gellan gum absorbs lesser extent in acidic conditions because of the carboxylic group of L-ascorbic acid becomes protonated to $\mathrm{COOH}$ and turns the materials less soluble $^{39}$. In pH 12, the solubility was increased due to the residue of D-glucoronic acid of carboxylic groups is in the anionic form. The maximum of water uptake in $\mathrm{pH} 7$ of the composite films are due to the highest number of anionic groups in buffer solution. The hydrophilicity properties of the norfloxacin itself also might be one another factor of the increasing of water uptake by the composite films.

For the released study of gellan gum with norfloxacin film, wavelength of $272 \mathrm{~nm}^{40}$ was selected for estimation of norfloxacin from the overlain spectra as shown in Fig. 3. The calibration curve was constructed by recording UV-Visible absorbance difference against concentration of norfloxacin.

The drug released was studies by using $0.01,0.1,0.5$, and $1 \% \mathrm{w} / \mathrm{w}$ concentration of norfloxacin as active materials. Norfloxacin was incorporated into the gellan gum solution to examine the release properties. The release study was investigated in controlled $\mathrm{pH}$ and standard temperature which is at $\mathrm{pH} 7$ and $37^{\circ} \mathrm{C}$, respectively. Since the composite film will be applied for pharmaceutical, so the neutral $\mathrm{pH}$ and human body temperature have been choose to control the conditions.

Fig. 4 shows the drug release behaviours of GG-NOR composite films in phosphate buffer solution. Based on the results, it shows that the amount of drug release was run out within $5 \mathrm{~min}$ for both GG-NOR001 and GG-NOR01, while within 10 and $20 \mathrm{~min}$ for GG-NOR05 and GG-NOR1, respectively. It shows that the concentrations of drug incorporated in the film influence the release rate of norfloxacin. The film incorporated with the lowest norfloxacin concentration shows the fastest release rate while the slowest release rate was shown by the highest incorporated drug. It is noted that the release rate of drug can be controlled with the norfloxacin content.

Apart from that, the released drug also controlled by absorbed water of gellan gum. The anionic side chains that presence in gellan gum molecules was enhanced the hydration activity causing it soluble in Milli-Q-water ${ }^{41}$. Gellan gum film will dissolve and forms pores filled with liquid and released the drug through diffusion process ${ }^{41}$.

The antibacterial activity of GG-NOR composite films was examined by qualitative (disk method) presented in Fig. 5. The inhibition zone was recorded after $24 \mathrm{~h}$ against Staphylococcus aureus and Escherichia coli executed by norfloxacin.

The incorporated of norfloxacin at high concentration inhibited the bacterial growth at larger diameter. For example, the GG-NOR1 composite films had inhibited 2.5 and 2.9 times larger than that of a GG-NOR001 composite film against Staphylococcus aureus and Escherichia coli, respectively. The inhibition zone of GG-NORO01 about $5.3 \mathrm{~mm}$ and $5.0 \mathrm{~mm}$, while GG-NOR1 inhibited about $13.0 \mathrm{~mm}$ and $14.3 \mathrm{~mm}$ resisted Staphylococcus aureus and Escherichia coli, respectively (Table 2 ).

The GG-NOR composite films were effective executed Gram-positive and Gram negative bacterial due to it could inhibits deoxyribonucleic acid synthesis intracellular in bacteria ${ }^{42-48}$. It was modified the enzyme structures and caused an abnormal change in production of polypeptide. Since it has different molecular structure compare to the other types of quinolones which has fluorine atom and piperazine ring at six and seven position, respectively, which is obtained from converting nalidixic acid into quinolone structure, it was offered dual effectiveness which is increased potency against gram-negative organisms and also provided antipseudomonal activity ${ }^{42}$.

\section{CONCLUSION}

The chemical and physical interaction also antibacterial activity of GG and GG-NOR film were examined. Based on the morphological observation, the smooth appearance of cross- 
section proved the blends was homogeneously mixed. The swelling properties were increased proportionally in $\mathrm{pH} 7$ to the concentration of norfoxacin. In contrast, the water vapour transmission rates value decreased with increased of norfoxacin added. The release rate of norfloxacin was increased with increase of the concentration norfloxacin incorporated in gellan gum film. Therefore, the inhibition zone was increased at higher concentration of norfloxacin incorporated into film.

\section{ACKNOWLEDGEMENTS}

The authors are grateful to Universiti Malaysia Terengganu (UMT) for financial assistance under internal research grant (TPM, Grant no. $68006 / 2012 / 46$ ) and for providing the facilities for undertaking this work.

\section{CONFLICTS OF INTEREST}

The authors declare that there is no conflict of interest.

\section{AUTHORS' CONTRIBUTIONS}

All authors listed have made a substantial, direct and intellectual contribution to the work, and approved it for publication.

\section{FUNDING}

This study was supported by research grant (TPM, Grant no. 68006/2012/46) from Universiti Malaysia Terengganu. The funders had no role on study design, data collection and analysis, decision to publish or preparation of the manuscript.

\section{DATA AVAILABILITY}

All datasets generated or analyzed during this study are included in the manuscript and/or the Supplementary Files.

\section{ETHICS STATEMENT}

This article does not contain any studies with human participants or animals performed by any of the authors.

\section{REFERENCES}

1. Paul F., Morin A., Monsan P. Biotechnology Advances, 1986; 4(2): 245-259.

2. Sutherland I.W. Biotechnology Advances 1994, 12(2):
393-448.

3. Rodr'guez-Hernandez A., Durand S., Garnier C., Tecante A., and Doublier J. Food Hydrocolloids, 2003; 17(5): 621-628.

4. Pszczola D.E. Food Technology, 1993; 47(9): 94-96.

5. Brownsey, G.J., Chilvers, G.R., I'Anson, K., Morris, V.J. International Journal Biology Macromolecule, 1984; 6: 211-14.

6. Lee M.-W., Chen H.-J., Tsao S.-W. Carbohydrate Polymers, 2010, 82(3): 920-926.

7. Smith A.M., Shelton R., Perrie Y., Harris J.J. Journal of Biomaterials Applications, 2007; 22(3): 241-254.

8. Balasubramaniam J., Kumar M.T., Pandit J.K., Kant S. Drug Delivery, 2004; 11(6): 371-379.

9. Greaves J.L., Wilson C.G., Rozier A., Grove J., Plazonnet B. Current Eye Research, 1990; 9(5): 415-420.

10. Wang C., Gong Y., Lin Y., Shen J., Wang D.-A. Acta Biomaterialia, 2008; 4(5): 1226-1234.

11. Oliveira J.T., Santos T.C., Martins L., Picciochi R., Marques A.P., Castro A.G., Neves N.M., Mano J.F., Reis R.L. Tissue Engineering Part A, 2009; 16(1): 343-353.

12. Mat Amin, K.A., Gilmore, K.J., Matic, J., Poon, S., Walker, M.J., Wilson, M.R.

Macromolecular Bioscience, 2012; 12(3): 374-382.

13. Ismail, N.A., Amin, K.A.M. and Razali, M.H. Novel gellan gum incorporated $\mathrm{TiO}_{2}$ nanotubes film for skin tissue engineering. Materials Letters, 2018; 228: 116-120.

14. Razali, M.H., Ismail, N.A., Zulkafli, M.F.A.M. and Amin, K.A.M., 3D Nanostructured materials: $\mathrm{TiO}_{2}$ nanoparticles incorporated gellan gum scaffold for photocatalyst and biomedical Applications. Materials Research Express, 2018; 5(3): 035039.

15. Emmerson, A., Jones, A. Journal of Antimicrobial Chemotherapy, 2003; 51: 13-20.

16. Van Bambeke, F., Michot, J.-M., Van Eldere, J., Tulkens, P.M. Clinical Microbiology and Infection, 2005; 11(4): 256-280.

17. Yan Wang, L.Z., Zhao D.; Shuyu X., Xiaojin C., Mengmeng L., Xiaofang W., Xihe L., Wen Zhong Z. Colloids and Surfaces B: Biointerfaces, 2012; 98: 105111.

18. Ni Y.N., Kokot, S. Spectrochimica Acta Part A, 2008; 70: 1049-1059.

19. Tong C.L., Huang G. Journal of Fluorescence, 2006; 16: 831-837.

20. Huang K.J., Xie, W. Z., Yuan, H. X. Colloids and Surfaces B: Biointerfaces, 2008; 64: 269-274.

21. Cui, J., Huang, Q., Yu, Y., Peng, X. Analytical Chimica Acta, 2011; 688: 84-89.

22. Khushboo N., Sayare, A., Ghode, P., Raymond M. Der Pharmacia Lettre, 2012; 4(1): 192-198.

23. Meijuan C. Journal of Hazardous Materials, 2012; 219-220: 183-189.

24. Barath S., Deveswaran R., Basavaraj V., Madhavan V. International Journal of Pharmaceutical Research and Development, 2012; 4(1): 16-21.

25. Malipeddi V.R., Dua K., Sara U.V.S., Malipeddi H., Agrawal A. Journal of Burns and Wounds, 2006, 5.

26. Dua K., Ramana M., Sara U., Agrawal D., Pabreja, K., Chakravarthi, S. Eplasty 2010; 10.

27. Hawkins C.L., Davies, M.J. Free Radical Biology and Medicine, 1998; 24(9): 1396-1410. 
28. Nitta Y., Kim B.S., Nishinari K. Biomacromolecules, 2003; 4: 1654-1660.

29. Wammer K.H., Korte A.R., Lundeen R. A., Sundberg J.E., McNeill K., Arnold W.A. Water Research, 2013; 47: 439-448.

30. Gonjari I.D., Javeera K.N., Kashikar V.S. Journal of Pharmacy Research, 2012; 5(3): 1620-1623.

31. Chen M.; Chu W. Journal of Hazardous Materials, 2012; 219-220: 183-189.

32. Qiao L., Jiazhen P., Zhiying H., Jianqiang B., Qiannan X. Scientific Research and Essays, 2014; 9(9): 391-399.

33. Silva C.L., Pereira J. C., Ramalho A., Pais A.A., Sousa, J.J. Journal of Membrane Science, 2008, 320(1): 268-279.

34. Nagahama H., Maeda, H., Kashiki T., Jayakumar, R., Furuike T., Tamura H. Carbohydrate Polymers, 2009; 76(2): 255-260.

35. Oliveira J.T., Martins L., Picciochi R., Malafaya, P., Sousa, R., Neves, N., Mano, J., Reis, R. Journal of Biomedical Materials Research Part A 2010, 93(3): 852-863.

36. Gouvea L.R., Garcia, L.S., Lachter D.R., Nunes P.R., FI בvia de Castro Pereira, Silveira-Lacerda, E. P., Louro, S.R.W., Barbeira, P.J.S., Teixeira, L.R. European Journal of Medicinal Chemistry, 2012; 55: 67-73.

37. Shaikh A.; Shaik P.; Pawar Y.; Kumbhar S., Katedeshmukh R. Journal Current Pharmaceutical Research, 2011, 6(1): 11-5.

38. Qadri S.M.; Johnson S. Journal of the National Medical Association, 1989; 81(4): 382-385.

39. Meler J., Grimling B., Pluta J., Progres on Chemistry and Application of Chitin and Its Derivatives, 2012; 17: 99-105.

40. Body B.A., Fromtling R.A., Shadomy H.J. European Journal of Clinical Microbiology, 1983; 2(3): 230-234.

41. Norrby S.R., Jonsson M. Antimicrobial Agents and Chemotherapy, 1983; 23(1): 15-18.

42. Shungu D.L., Weinberg E., Gadebusch H.H. Antimicrobial Agents and Chemotherapy, 1983; 23(1): 86-90.

43. Barry A., Jones R., Thornsberry C., Ayers L., Gerlach E., Sommers H. Antimicrobial Agents and Chemotherapy, 1984; 25(5): 633-637.

44. Cohen S.P., Hooper D., Wolfson J., Souza K., McMurry L., Levy S. Antimicrobial Agents and Chemotherapy, 1988; 32(8): 1187-1191. 